\title{
DNA barcoding confirms the occurrence of Rhamdia branneri and Rhamdia voulezi (Siluriformes: Heptapteridae) in the Iguaçu River Basin
}

\author{
Josiane Ribolli ${ }^{1}$, Bianca Maria Scaranto ${ }^{1}$, Oscar Akio Shibatta ${ }^{2}$, Robie Allan Bombardelli ${ }^{3}$ \\ and Evoy Zaniboni-Filho ${ }^{1}$
}

DNA barcoding is a widely utilized molecular-based identification of species and taxonomic resolutions. Until recently, Rhamdia voulezi and Rhamdia branneri were considered species synonyms of Rhamdia quelen; however, morphological and cytogenetic analyses have suggested the validity of distinct species. Due to the absence of molecular taxonomy of $R$. voulezi and $R$. branneri, the objective of this study was to test its validity through traditional DNA barcoding and the GMYC (General Mixed Yule Coalescent) COI-based analyses in 19 specimens from the Iguaçu River Basin. In both methodologies, three MOTUs (Molecular Operational Taxonomic Units) were identified based on the estimated optimum threshold (OT = 0.77). The average inter-MOTU distance (NJ, K2P) between $R$. branneri and $R$. voulezi was $1.4 \%$, and $0 \%$ intra-MOTU distance in both species. The two species identified as $R$. branneri and $R$. voulezi showed correspondence with taxonomic and morphological identifications. With regard to $R$. quelen, the average intra-MOTU distance was greater than OT $(2.7 \%)$, indicating that this species can be formed by different MOTUs. We suggest that molecular and taxonomic studies should be employed concurrently in $R$. quelen, to prevent contamination of wild species by hybridizations.

Keywords: Aquaculture, COI, Jundiá, MOTU, Species complex.

O DNA barcoding é uma ferramenta molecular precisa para a identificação de espécies e resoluções taxonômicas. Até recentemente, Rhamdia voulezi e Rhamdia branneri eram consideradas sinônimas de Rhamdia quelen, contudo caracteres morfológicos e citogenéticos têm apontado à validade de ambas. Devido à escassez de informações sobre a taxonomia molecular de $R$. voulezi e $R$. branneri, o objetivo do presente estudo foi testar a validade das mesmas através do método de DNA barcoding tradicional e GMYC (General Mixed Yule Coalescent), por meio da análise do gene COI em 19 espécimes do rio Iguaçu. Em ambos os métodos, três MOTUs (Unidades Taxonômicas Operacionais Moleculares) foram identificadas com base no ótimo threshold $(\mathrm{OT}=0,77)$. A média inter-MOTU (NJ, K2P) entre $R$. branneri e $R$. voulezi foi $1,4 \%$, com valores de $0 \%$ intra-MOTUs em ambas espécies. As duas espécies identificadas como $R$. voulezi e $R$. branneri apresentaram correspondência com a identificação taxonômica e morfológica dos respectivos vouchers. No que se refere a $R$. quelen, os resultados intra-MOTU foram superiores ao OT $(2,7 \%)$, evidenciando a possibilidade de existirem diferentes MOTUs denominadas como $R$. quelen. Sugerimos que estudos moleculares e taxonômicos sejam empregados em $R$. quelen, para evitar a contaminação de espécies selvagens por hibridizações.

Palavras-chave: Aquicultura, COI, Complexo de espécies, Jundiá, MOTU.

\section{Introduction}

DNA barcoding is a widely molecular-based identification system utilized to identify biological specimens based on a short standardized sequence of DNA (Hebert et al. 2003a,b). The integration between the molecular and traditional taxonomic identification is a relevant association and can promote the identification of a greater number of species than currently described (Steinke, Hanner, 2011). Presently, there is a range of studies addressing the Neotropical ichthyofauna through DNA barcoding, suggesting and revealing several new species (Pereira et al., 2011; Rosso et al., 2012; Gomes et al., 2015; Ramirez, Galetti Jr., 2015; Melo et al., 2016). However, the success of the identification of species from molecular data depends on the precise taxonomic identification and availability of reference sequences (Ward et al., 2009).

\footnotetext{
${ }^{1}$ Laboratório de Biologia e Cultivo de Peixes de Água Doce, Universidade Federal de Santa Catarina, Rod. SC 403, 3532, 88066-260 Florianópolis, SC, Brazil. (JR) josianeribolli@gmail.com (corresponding author), (BMS) biascaranto@gmail.com, (EZF) evoy@lapad.ufsc.br ${ }^{2}$ Campus Universitário, Centro de Ciências Biológicas, Departamento de Biologia Animal e Vegetal, Universidade Estadual de Londrina, Caixa postal 10011, 86057-970 Londrina, PR, Brazil.shibatta@uel.br

${ }^{3}$ Grupo de Pesquisa em Química, Meio Ambiente e Aquicultura, Universidade Estadual do Oeste do Paraná. Caixa Postal 320, 85903-000

Toledo, PR, Brazil. rabombardelli@gmail.com
} 
The genus Rhamdia was considered the most specious in the Heptapteridae family, with approximately 100 species, in which the vast majority of species has great similarities in body shape, color pattern and habitat use. In a review carried out by Silfvergrip (1996), all described species were narrowed down to only 11 valid species, in which 49 species were synonimized as Rhamdia quelen. Among the clustered species discussed by Silfvergrip (1996), Rhamdia branneri Haseman, 1911 and Rhamdia voulezi Haseman, 1911, both from Iguaçu River Basin, were also recognized as synonyms of $R$. quelen (Quoy, Gaimard, 1824). Nevertheless, recent cytogenetic and morphometric studies have disagreed with Silfvergrip's revision. The characteristics associated with chromosome $\mathrm{B}$ and karyotype variations between species of the genus Rhamdia from the Iguaçu River, for example, showed that $R$. voulezi and $R$. branneri are distinct from $R$. quelen (Abucarma, Martins-Santos, 2001; Garcia et al., 2010). Recently Mise et al. (2013) and Garavello, Shibatta (2016) detected evident morphometric characteristics for the reappraisal of $R$. branneri and $R$. voulezi from the Iguaçu River Basin.

According to Garavello, Shibatta (2016), R. voulezi and $R$. branneri exhibit some morphometric differences in the length of the adipose fin and the maxillary barbel as well as a deeper caudal peduncle (for more details see Garavello, Shibatta, 2016). According to those authors, both species differ from $R$. quelen by the fine serrate margin of pectoralfin spine, dorsal dark-brown or light-gray coloration along body, and abdomen pale, without profuse small black spots. Prior to being considered synonyms of $R$. quelen, $R$. branneri and $R$. voulezi were described as endemic to the Iguaçu River Basin, Southern Brazil (Garavello, Shibatta, 2007; Garavello et al., 2012; Baumgartner et al., 2012; Garavello, Shibatta, 2016).

Thus, given the taxonomic evidence supported by recent studies, we used DNA barcoding and species delimitation methods to confirm the validity of $R$. branneri and $R$. voulezi. These results will contribute to the knowledge of this complex genus, which may be formed by a larger number of species, which are currently cultivated and commercialized only as the common name, jundiá.

\section{Materials and methods}

Sampling and taxonomic identification. Nineteen specimens of $R$. voulezi and $R$. branneri from the Iguaçu River Basin (Tab. 1) were sampled. Of these, three vouchers were deposited in the ichthyological collection of the Museu de Zoologia of the Universidade Estadual de Londrina (one $R$. voulezi (MZUEL 16503, specimen 3619) and two $R$. branneri (MZUEL 16504, specimens 3630 and 3638)). The specimens were identified following Haseman (1911) and Garavello, Shibatta (2016). Principal Components Analysis was employed to describe morphometric differences among vouchers of $R$. branneri and $R$. voulezi, using the program PAST (Hammer et al., 2001) on 11 log transformed morphometric variables.

Tab. 1. Specimen information, voucher identification and BOLD accession numbers for the Rhamdia branneri and Rhamdia voulezi analyses. All samples were collected by Robie Bombardelli.

\begin{tabular}{|c|c|c|c|c|c|c|c|}
\hline Samples & BOLD access & Species & Locality & River & Latitude & Longitude & Voucher Number \\
\hline 3621 & BRH001-16 & R. branneri & Salto Osório Reservoir & Iguaçu & -25.621003 & -52.620797 & MZUEL 16504 \\
\hline 3630 & BRH002-16 & R. branneri & Salto Osório Reservoir & Iguaçu & -25.621003 & -52.620797 & MZUEL 16504 \\
\hline 3632 & BRH004-16 & R. branneri & Salto Osório Reservoir & Iguaçu & -25.621003 & -52.620797 & MZUEL 16504 \\
\hline 3633 & BRH005-16 & R. branneri & Salto Osório Reservoir & Iguaçu & -25.621003 & -52.620797 & MZUEL 16504 \\
\hline 3636 & BRH008-16 & R. branneri & Salto Osório Reservoir & Iguaçu & -25.621003 & -52.620797 & MZUEL 16504 \\
\hline 3638 & BRH009-16 & R. branneri & Salto Osório Reservoir & Iguaçu & -25.621003 & -52.620797 & MZUEL 16504 \\
\hline 3640 & BRH010-16 & R. branneri & Salto Osório Reservoir & Iguaçu & -25.621003 & -52.620797 & MZUEL 16504 \\
\hline 3640 & BRH011-16 & R. branneri & Salto Osório Reservoir & Iguaçu & -25.621003 & -52.620797 & MZUEL 16504 \\
\hline 3619 & BRH015-16 & R. voulezi & Salto Osório Reservoir & Iguaçu & -25.621003 & -52.620797 & MZUEL 16503 \\
\hline 3624 & BRH016-16 & R. voulezi & Salto Osório Reservoir & Iguaçu & -25.621003 & -52.620797 & MZUEL 16503 \\
\hline 3625 & BRH017-16 & R. voulezi & Salto Osório Reservoir & Iguaçu & -25.621003 & -52.620797 & MZUEL 16503 \\
\hline 3628 & BRH018-16 & R. voulezi & Salto Osório Reservoir & Iguaçu & -25.621003 & -52.620797 & MZUEL 16503 \\
\hline 3629 & BRH019-16 & R. voulezi & Salto Osório Reservoir & Iguaçu & -25.621003 & -52.620797 & MZUEL 16503 \\
\hline
\end{tabular}


DNA barcoding analysis. Total genomic DNA was extracted from fin tissues preserved in ethanol using a method described by Aljanabi, Martinez (1997). Partial sequences of the mitochondrial gene COI were amplified using the Fish-F1 and Fish-R1 primers (Ward et al., 2005), following the PCR method proposed by Bellafronte et al. (2013). PCR products were visualized on a $1 \%$ agarose gel and purified with 20\% PEG (Lis, 1980). Sequencing reactions were performed using BigDye TM Terminator v 3.1 (Cycle Sequencing Ready Reaction Kit, Applied Biosystems), and the PCR products were sequenced for both strands in ABI 3500XL (Applied Biosystems). Contigs were then assembled and edited using BioEdit v. 7.2 .5 (http:// www.mbio.ncsu.edu/bioedit/bioedit.html). BOLD accession numbers are given in Tab. 1.

We combine our dataset with the following sequences available in the public reference database BOLD system (http://www.boldsystems.org): Rhamdia guatemalensis (code HBGM) as outgroup, and Rhamdia quelen (we used samples from two different basins due to broad distribution of this species: code BSB, Upper Paraná River Basin and code ITAPE, Itapecuru River Basin). The traditional DNA barcoding method was based on the genetic distance between a pair of sequences, using the Kimura 2-parameter (K2P) model. The expectation of this method is that individuals of the same species have lower genetic distance (intraspecific variation) compared to individuals of other species (interspecific variation) (Hebert et al., 2003a), based on chosen threshold. The optimum threshold (OT; Collins et al., 2012) was calculated using the localMinima function, using the R package SPIDER (Species IDentity and Evolution; Brown et al., 2012). SPIDER is a R package implementing a number of useful analyses for DNA barcode studies and research into species delimitation and speciation, with functions essential for generating statistics from DNA barcode data, allowing optimizing divergence threshold limits based on the concept of the barcoding gap (Meyer, Paulay, 2005). For details about the software and download of package see Brown et al., 2012 and SIPER web site (http:// spider.r-forge.r-project.org/SpiderWebSite/spider.html). The advantage of this method is that it does not require a priori knowledge about the identity of the species and minimizes error (barcoding gaps) (Meyer, Paulay, 2005; Brown et al., 2012). The optimum threshold value was used to define the molecular operational taxonomic units (MOTUs) using JMOTU (Jones et al., 2011). The graphical representation of the MOTUs was performed by neighbor-joining analysis (NJ) using the K2P model, implemented in the software Mega 6.6 (Tamura et al., 2013). The support of clades was tested by the bootstrap method containing 10,000 pseudo replicates.

The General Mixed Yule Coalescent (GMYC) is a phylogenetic approach for species delimitation based on single-locus data that combines a coalescent model that is a relative robust tool for species delimitation (Pons et al., 2006; Fujisawa, Barraclough, 2013). This approach requires an ultrametric tree and predicts that difference in branching rates between the events of inter-specific or intraspecific relations, based on the length of the branches (Pons et al., 2006). The ultrametric tree was generated in BEAST v.2.2.1 (Bouckaert et al., 2014), with the substitution model calculated in the JModelTest 2.1.4 (Posada, 2008 - HKY+G), using relaxed molecular clock with a lognormal distribution and birth-death model. Three independent runs were carried out with 10 million generations each. Posteriorly, the runs were combined using the LogCombiner v.1.8.3 (Drummond et al., 2012), with a burn-in of $25 \%$, as method suggested by Machado et al. (2016). Data mixing and effective sample size (ESS) were verified in Tracer v1.5. GMYC was carried out in SPLITs (Species Limits by Threshold Statistics; Monaghan et al., 2009) with RStudio (http://r-forge.r-project.org/ projects/ splits), using the unique threshold method to detect the transition point between intra- and interspecific relationships.

\section{Results}

Taxonomy. Morphometric characters of specimens deposited as vouchers of $R$. branneri and $R$. voulezi showed the same morphological pattern indicated by Garavello, Shibatta (2016). The first axis of PCA represents the size, evidencing linear differences among $R$. branneri (vouchers MZUEL 16504, specimen 3630 with $303.3 \mathrm{~mm}$ SL (Fig. 1a) larger than specimen 3638 with $251.0 \mathrm{~mm} \mathrm{SL}$ ) (Fig. 2). Both $R$. branneri differ in body shape from $R$. voulezi specimen 3619 (MZUEL 16503, Fig. 1b) in the second axis of PCA, with the larger distance between the dorsal and adipose fins (5.1\% and $6.5 \%$ of the standard length (SL), in R. branneri versus $9.6 \%$ of the $\mathrm{SL}$ in $R$. voulezi) (Tab. 2).

DNA barcoding. The sequences from 19 specimens were deposited in the BOLD database, specifically in the project entitled Barcoding Rhamdia (BRH). Because there are not insertions, deletions, or stop codons, pseudogenes, were not amplified. The sequences of $R$. voulezi and $R$. branneri resulted in $562 \mathrm{bp}$, while the sequences obtained from the BOLD database ranged from 582 to $652 \mathrm{bp}$. All individuals of the genus Rhamdia showed 109 positions that were parsimony informative, and nine differed between $R$. branneri and $R$. voulezi sequences. The OT value for the dataset analyzed was $0.77 \%$, and three MOTUs (correspondent to R. branneri, $R$. voulezi, and $R$. quelen) were identified using this cut-off value as a barcode threshold in jMOTU. Phylogenetic trees (NJ and Bayesian inference) showed congruent topology and were strongly supported (Fig. 3) for $R$. branneri, R. voulezi, $R$. quelen from the Upper Paraná basin (BSB) and from the Itapecuru River (ITAPE), and $R$. guatemalensis. If these four species are considered equally valid ( $R$. voulezi, $R$. branneri, $R$. quelen and $R$. guatemalensis), only $R$. quelen has an intraMOTU divergence higher than the OT (2.7\%), suggesting the presence of cryptic genetic diversity (Tab. 3). On the other hand, as expected by the DNA barcoding method, interMOTU values were greater than the OT values in all pairwise comparisons (Tab. 3). 


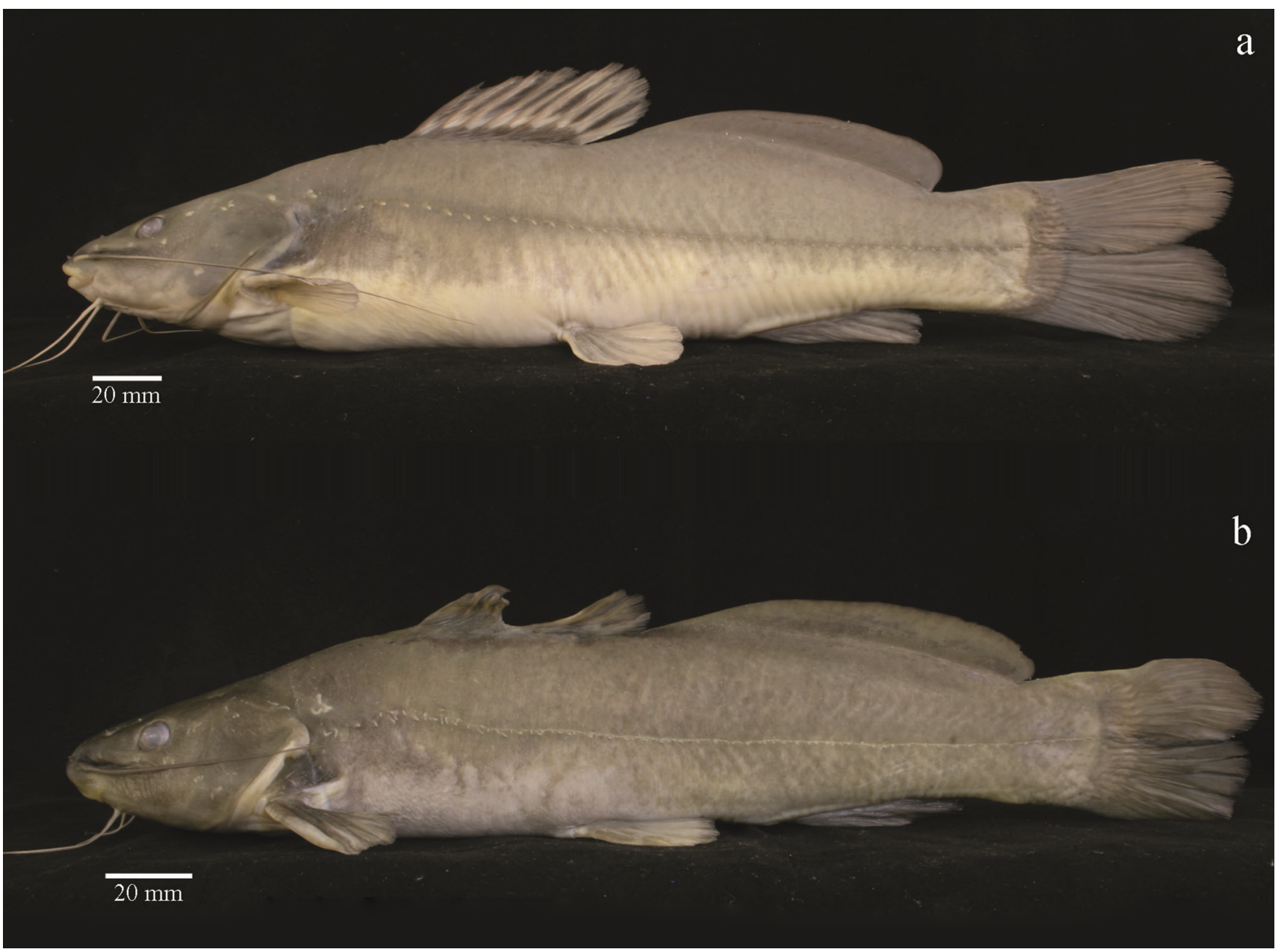

Fig. 1. Lateral view of a. Rhamdia branneri (BRH009-16; MZUEL 16504) 303.34 mm SL and b. Rhamdia voulezi (BRH01516; MZUEL 16503) 300.8 mm SL from the Iguaçu River Basin, Paraná State, Brazil.

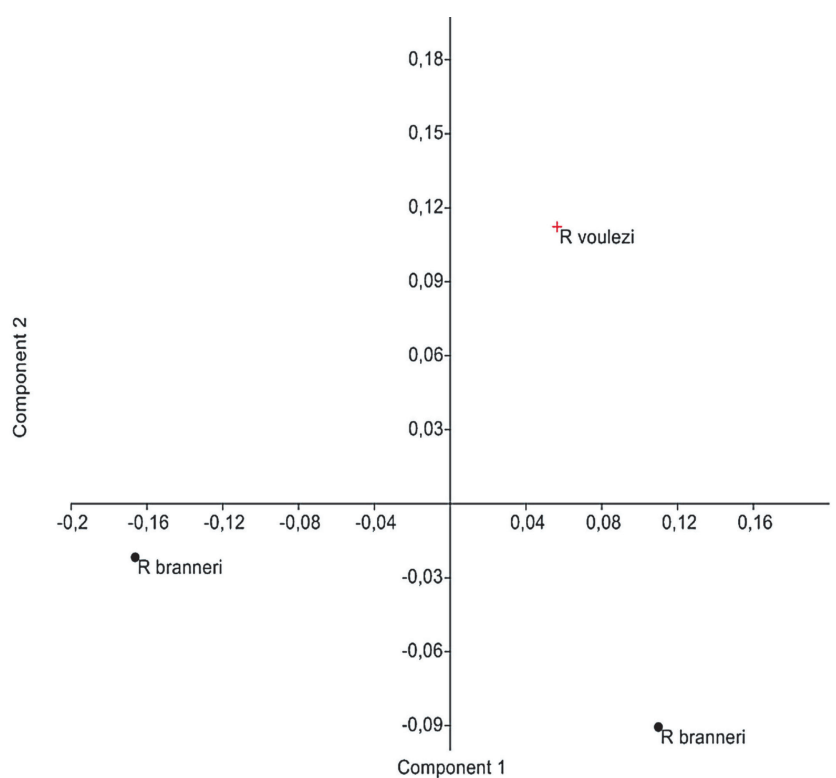

Fig. 2. Principal components analysis of Rhamdia voulezi and Rhamdia branneri from the Iguaçu River Basin, Paraná State, Brazil.
Tab. 2. Variable loading on the first and second axis of the principal components analysis of Rhamdia voulezi and Rhamdia branneri from Iguaçu River Basin, Paraná State, Brazil.

\begin{tabular}{lcc}
\hline Variable & Axis 1 & Axis 2 \\
\hline Head length & 0.3493 & 0.0626 \\
Orbital diameter & 0.1991 & 0.2041 \\
Maxillary barbel length & 0.2749 & -0.3599 \\
Predorsal distance & 0.2879 & 0.0004 \\
Dorsal-fin base length & 0.3322 & -0.1903 \\
Dorsal fin to adipose fin distance & -0.05536 & 0.8025 \\
Adipose-fin base length & 0.3392 & 0.1785 \\
Prepelvic length & 0.395 & -0.0272 \\
Anal-fin base length & 0.09651 & -0.0556 \\
Caudal peduncle depth & 0.304 & -0.1189 \\
Caudal peduncle length & 0.4401 & 0.3081 \\
Eigenvalue & 0.0214473 & 0.0106 \\
Percent of variance & $66.85 \%$ & $33.14 \%$ \\
\hline
\end{tabular}


The maximum likelihood for the GMYC model was significantly higher $(\mathrm{L}=224.13)$ than the null model $\left(\mathrm{L}_{0}=\right.$ 220.09, $\mathrm{p}$-value $=0.01)$. The transition point between the coalescence and speciation/extinction processes had close correspondence with the five groups obtained by the traditional DNA barcoding analysis (dotted vertical line in Fig. 3).

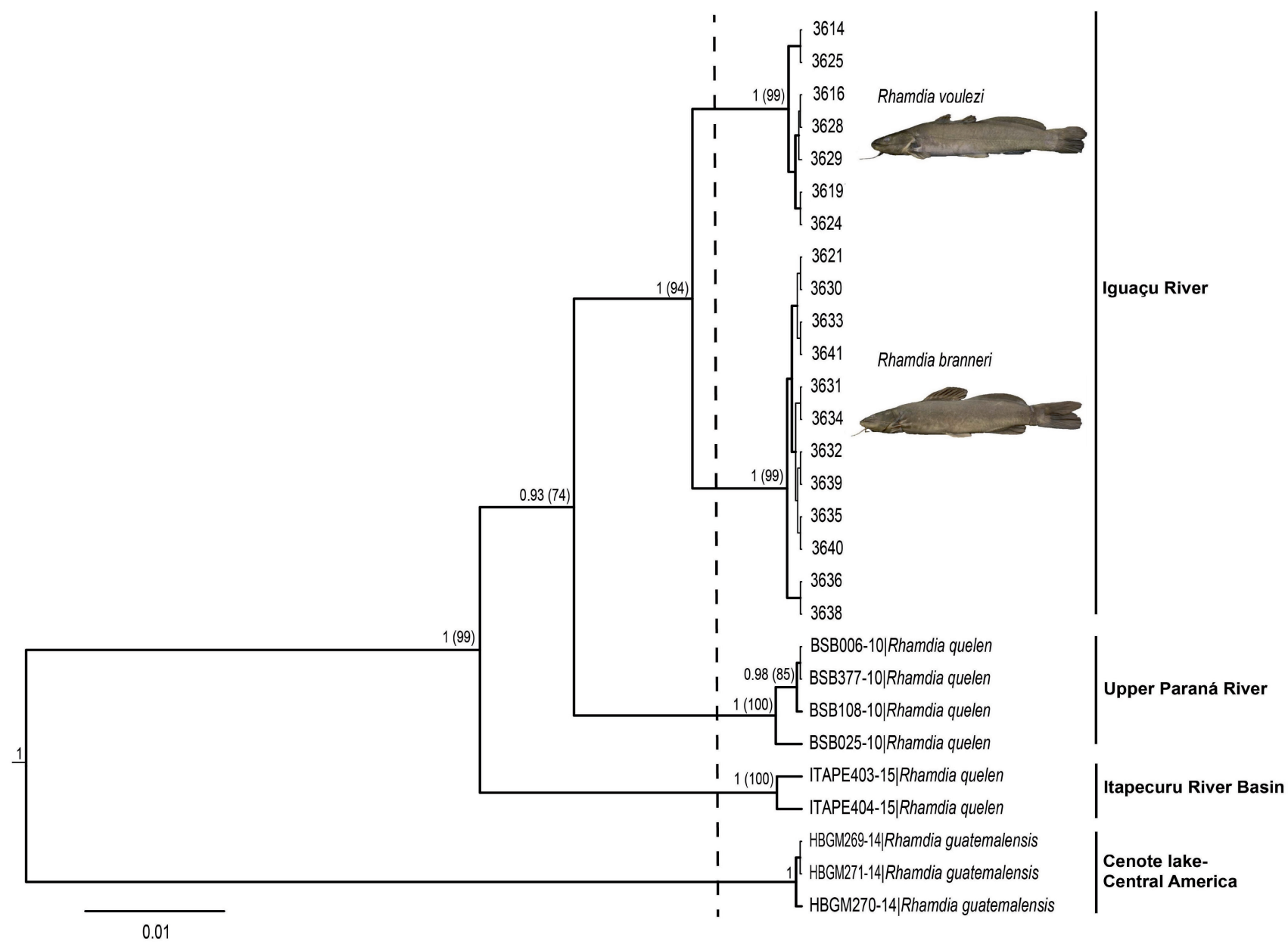

Fig. 3. The Bayesian inference tree obtained using the COI gene in BEAST v1.8.3. The numbers above the branches are the probability values (posterior probability) for the Bayesian model and the values in parentheses represent the NJ-K2P model, with a bootstrap of 1000 replicates. The vertical line indicates the species delimitation assigned by the single-threshold method in GMYC analysis. Photos by Tiago Debona.

Tab. 3. Intra- (in bold) and inter-MOTU genetic distances using the $\mathrm{COI}$ gene and the $\mathrm{K} 2 \mathrm{P}$ model (Optimized threshold value $=0.77 \%$ ). Values are shown as percentages. ${ }^{1}$ Sequences from the BOLD data system.

\begin{tabular}{lcccc}
\hline Species & 1 & 2 & 3 & 4 \\
\hline 1. Rhamdia voulezi & $\mathbf{0 . 0}$ & & & \\
2. Rhamdia branneri Rhamdia quelen $^{1}$ & 1.4 & $\mathbf{0 . 0}$ & & \\
${\text { 4. } \text { Rhamdia guatemalensis }^{1}}^{1}$ & 3.2 & 3.9 & $\mathbf{2 . 7}$ & \\
\hline
\end{tabular}

\section{Discussion}

DNA barcoding analysis identified $R$. branneri and $R$. voulezi as distinct MOTUs, corroborating with reappraisal suggested by Garavello, Shibatta (2016). According to these authors, $R$. branneri and $R$. voulezi have morphological characteristics that permit its discrimination and maintenance of the names, such as the morphology of the dorsal and adipose fins, maxillary barbels, morphometric characteristics and pigmentation. In addition, both species exhibited inter-MOTU divergences higher than OT in comparison with $R$. quelen ( $>3.2 \%$, Tab. 3 ).

Inter-MOTU distances were assessed using a method that calculates specific OT values from the analyzed dataset. Originally, DNA barcoding analysis applied the cut-off threshold of $1 \%$ for the analyzed species delimitation (Ratnasingham, Hebert, 2007). In specific groups, such as the Neotropical fish, studies have used the barcoding threshold (approximately 2\%) proposed by Ward (2009) to delimit a wide-range of species (Rosso et al., 2012; Bellafronte et al,. 2013; Pereira et al., 2013; Gomes et al., 2015; Shimabukuro-Dias et al., 2016; Díaz et al., 2016). Nonetheless, given the great diversity of 
species, particularly related to life histories and complexity of environment, a fixed threshold value can under- or overestimate the correct number of MOTUs (Brown et al., 2012). The optimized threshold avoids pre-defined cut-off values, minimizing false positive or false negative errors (Collins et al., 2012). When examining the sequences of the Rhamdia genus (Tab. 3), we found that if the cut-off value is used as suggested for Neotropical fish (2\%), the molecular identification would be underestimated, with only four MOTUs. As the genetic distance between $R$. branneri and $R$. voulezi was $1.4 \%$ (Tab. 3), these two taxonomically distinct species should be considered a single MOTU. In this way, the OT calculated from our dataset allowed the correct identification of all five MOTUs, demonstrating its ability to discriminate these species from the target species in this study.

Taxonomic analysis of the Rhamdia genus is complex; the species present great similarity in morphological characteristics, making its identification more difficult and generating ample controversy. Originally described by Haseman (1911) as R. branneri and R. branneri voulezi, both species were reported as endemic from the Iguaçu River Basin. Some studies have had evidence to refute the taxonomic revision proposed by Silfvergrip (1996), where $R$. voulezi and $R$. branneri were considered synonyms of $R$. quelen. With regard to karyotype differentiation and the presence of chromosome $\mathrm{B}$ in $R$. branneri and $R$. voulezi, Abucarma, Martins-Santos (2001) found a range of chromosomes (58-62) that overlap in number for both species. However, $R$. voulezi and $R$. branneri can be differentiated by the morphology of chromosome B, which can be used as a specific marker (Abucarma, MartinsSantos, 2001).

Although there is overlap in the number of chromosomes, morphological studies support the evidence in considering $R$. voulezi and $R$. branneri as valid independent species (Garcia, 2009; Baumgartner et al., 2012; Mise et al., 2013). Recently, Garavello, Shibatta (2016) described a series of morphological characteristics that discriminate between $R$. voulezi and $R$. branneri, suggesting provision of the names for both. The method applied by Garavello, Shibatta (2016) and the DNA barcoding were congruent and conclusive in identifying $R$. branneri and $R$. voulezi as valid and separating both species from $R$. quelen.

Representatives of $R$. branneri and $R$. voulezi are cultivated and commercialized for fish-farms and feefishing farms only as jundiá (same common name used for $R$. quelen). The confirmation and validation of $R$. branneri and $R$. voulezi, based on both morphological characters (Garavello, Shibatta, 2016) and molecular data, contribute to the conservation of the genetic resources of these species, preventing genetic contamination for the production of unintended hybrids. According to Hashimoto et al., (2016), the negative impacts resultant from the erroneous use of hybrids in the genetic integrity of wild pure species are not considered by fish farmers. Problems related to wild populations produced for inappropriate crosses can also be damaging to aquaculture activity (Belle, Nash, 2009). In addition, the correct identification of the species contributes to genetic breeding and the integrity of natural stocks (Hashimoto et al., 2011).

DNA barcoding analysis corroborates the morphological (Shibatta, Garavello, 1995; Garavello, Shibatta, 2016), karyotypic (Abucarma, Martins-Santos, 2001; Moraes et al., 2007; Garcia et al., 2003; Garcia et al., 2010; Martinez et al., 2011) and ecomorphological studies (Mise et al., 2013), confirming $R$. branneri and $R$. voulezi as valid species. The correct definition of MOTUs and definition of the species is essential to the conservation of wild stocks and to minimizing the possibility of species translocations through aquaculture activity. At last, we strongly indicate the molecular and taxonomic analysis of Rhamdia quelen, which, due to the high level of intraspecific divergences in the analyzed data, shows cryptic genetic diversity that needs to be thoroughly evaluated.

\section{Acknowledgments}

We thank our colleagues from the Laboratório de Biologia e Cultivo de Peixes de Água Doce (LAPAD/UFSC). We are grateful to Carolina Machado for her important contributions to this manuscript. JR and BMS acknowledge scholarships provided by PNPD/CAPES and PROEX/ CAPES, respectively. EZF thanks Conselho Nacional de Desenvolvimento Científico e Tecnológico (CNPq, grant 302860/2014-2) for his research productivity grant.

\section{References}

Abucarma M, Martins-Santos IC. Karyotype and B chromosome of Rhamdia species (Pisces, Pimelodidae) endemic in the River Iguaçu basin. Cytologia. 2001; 66(3):299-306.

Aljanabi SM, Martinez I. Universal and rapid salt-extraction of high quality genomic DNA for PCR-based techniques. Nucleic Acids Res. 1997; 25(22):4692-93.

Baumgartner G, Pavanelli CS, Baumgartner D, Bifi AG, Debona T, Frana VA. Peixes do baixo rio Iguaçu. Maringá: Eduem; 2012.

Bellafronte E, Mariguela TC, Pereira LHG, Oliveira C, MoreiraFilho O. DNA barcoding of Parodontidae species from the La Plata river basin - applying new data to clarify taxonomic problems. Neotrop Ichthyol. 2013; 11(3):497-506.

Belle SM, Nash CE. Better management practices for netpen aquaculture. In: Tucker CS, Hargreaves JA, editors. Environmental best management practices for aquaculture. Oxford: Wiley-Blackwell ; 2009. p. 261-330.

Bouckaert R, Heled J, Kühnert D, Vaughan T, Wu CH, Xie D et al. BEAST 2: a software platform for Bayesian evolutionary analysis. PLoS Comput Biol. 2014; 10(4):e1003537.

Collins RA, Boykin LM, Cruickshank RH, Armstrong KF. Barcoding's next top model: an evaluation of nucleotide substitution models for specimen identification. Methods Ecol Evol. 2012; 3 (3):457-65. 
Drummond AJ, Suchard MA, Xie D, Rambaut A. Bayesian phylogenetics with BEAUTi and the BEAST 1.7. Mol Biol Evol. 2012; 29(29):1969-73.

Brown SD, Collins RA, Boyer S, Lefort MC, Malumbres-Olarte J, Vink CJ et al. SPIDER: an R package for the analysis of species identity and evolution, with particular reference to DNA barcoding. Mol Ecol Res. 2012; 12(3):562-65.

Díaz J, Villanova GV, Brancolini F, Del Pazo F, Posner VM, Grimberg A et al. First DNA barcode reference library for the identification of South American freshwater fish from the lower Paraná River. PloS ONE. 2016; 11(7):e0157419.

Fujisawa T, Barraclough TG. Delimiting species using singlelocus data and the Generalized Mixed Yule Coalescent (GMYC) approach: a revised method and evaluation on simulated datasets. Syst Biol. 2013; 62(5):707-24.

Garavello JC, Britski HA, Zawadzki CH. The cascudos of the genus Hypostomus Lacépède (Ostariophysi: Loricariidae) from the rio Iguaçu basin. Neotrop Ichthyol. 2012; 10(2):263-83.

Garavello JC, Shibatta OA. A new species of the genus Pimelodus La Cépède, 1803 from the rio Iguaçu basin and a reappraisal of Pimelodus ortmanni Haseman, 1911 from the rio Paraná system, Brazil (Ostariophysi: Siluriformes: Pimelodidae). Neotrop Ichthyol. 2007; 5(3):285-92.

Garavello JC, Shibatta OA. Reappraisal of Rhamdia branneri Haseman, 1911 and $R$. voulezi Haseman, 1911 (Siluriformes: Heptapteridae) from the rio Iguaçu with notes on their morphometry and karyotype. Neotrop Ichthyol. 2016; 14(1):e140111.

Garcia C. Estudos cromossômicos e moleculares em Rhamdia (Pisces, Siluriformes, Heptapteridae): analise de relações evolutivas. [PhD Thesis]. São Paulo, SP: Instituto de Biociencias da Universidade de São Paulo; 2009.

Garcia C, Moreira-Filho O, Bertollo LAC, Centofante L. B chromosomes and natural triploidy in Rhamdia sp. (Pisces, Siluriformes, Heptapteridae). Cytologia. 2003; 68(4):403-11.

Garcia C, Oliveira C, Almeida-Toledo LF. Karyotypic evolution trends in Rhamdia quelen (Siluriformes, Heptapteridae) with considerations about the origin and differentiation of its supernumerary chromosomes. Genet Mol Res. 2010; 9(1):365-84.

Gomes LC, Pessali TC, Sales NG, Pompeu PS, Carvalho DC. Integrative taxonomy detects cryptic and overlooked fish species in a neotropical river basin. Genetica. 2015; 143(5):581-88.

Hammer $\varnothing$, Harper DAT, Ryan PD. PAST: Palaeontological Statistics Software Package for education and data analysis. Palaeontol Electron. 2001; 4(1):1-9.

Haseman JD. Some new species of fishes from the rio Iguassú. Annals of the Carnegie Museum. 1911; 7:374-87.

Hashimoto DT, Mendonça FF, Senhorini JA, Oliveira C, Foresti F, Porto-Foresti F. Molecular diagnostic methods for identifying Serrasalmid fish (Pacu, Pirapitinga, and Tambaqui) and their hybrids in the Brazilian aquaculture industry. Aquaculture. 2011; 321(1-2):49-53.

Hashimoto DT, Prado FD, Foresti F, Porto-Foresti F. Molecular identification of intergenus crosses involving catfish hybrids: risks for aquaculture production. Neotrop Ichthyol. 2016; 14(2):e150139.
Hebert PDN, Cywinska A, Ball SL, deWaard JR. Biological identifications through DNA barcodings. Proc R Soc B. 2003a; 270(1512):313-21.

Hebert PDN, Ratnasingham S, de Waard JR. Barcoding animal life: cytochrome c oxidase subunit 1 divergences among closely related species. Proc R Soc B. 2003b; 270(1):S96-S99.

Jones M, Ghoorah A, Blaxter M. jMOTU and Taxonerator: turning DNA barcode sequences into annotated operational taxonomic units. PLoS ONE. 2011; 6(4):e19259.

Lis JT. Fractionation of DNA fragments by polyethylene glycol induced precipitation. Methods Enzymol. 1980; 65(1):347-53.

Machado CDB, Ishizuka TK, Freitas PDD, Valiati VH, Galetti Jr. PM. DNA barcoding reveals taxonomic uncertainty in Salminus (Characiformes). Syst Biodivers. 2016;1-11.

Martinez JF, Lui RL, Blanco DR, Traldi JB, Silva LF, Venere PC et al. Comparative cytogenetics of three populations from the Rhamdia quelen species complex (Siluriformes, Heptapteridae) in two Brazilian hydrographic basins. Caryologia. 2011; 64(1):121-28.

Melo BF, Ochoa LE, Vari P, Oliveira C. Cryptic species in the Neotropical fish genus Curimatopsis (Teleostei, Characiformes). Zool Scrip. 2016; 45(6):650-58.

Meyer C, Paulay P. DNA barcoding: error rates based on comprehensive sampling. PLoS Biol. 2005; 3(12):e422.

Mise FT, Tencatt LFC, Souza F. Ecomorphological differences between Rhamdia (Bleeker, 1858) populations from the Iguaçu River basin. Biota Neotrop. 2013; 13(4):99-104.

Monaghan MT, Wild R, Elliot M, Fujisawa T, Balke M, Inward DJG et al. Accelerated species inventory on Madagascar using coalescent-based models of species delineation. Syst Biol. 2009; 58(3):298-311.

Moraes VPO, Cereali SS, Froehlich O, Dias AL. Cytogenetic characterization of Rhamdia quelen (Siluriformes, Heptapteridae) from the Bodoquena Plateau, Mato Grosso do Sul, Brazil. Genet Molec Res. 2007; 6(3):627-33.

Pereira LHG, Maia GMG, Hanner R, Foresti F, Oliveira C. DNA barcodes discriminate freshwater fishes from the Paraíba do Sul River Basin, São Paulo, Brazil. Mitochondr DNA. 2011; 22(S1):71-79.

Pereira LHG, Hanner R, Foresti F, Oliveira C. Can DNA barcoding accurately discriminate megadiverse Neotropical freshwater fish fauna? BMC Genetics. 2013; 14(20):1-14.

Pons J, Barraclough TG, Gomez-Zurita J, Cardoso A, Duran DP, Hazell S et al. Sequence-based species delimitation for the DNA taxonomy of undescribed insects. Syst Biol. 2006; 55(4):595-609.

Posada D. jModelTest: phylogenetic model averaging. Mol Biol Evol. 2008; 25(7):1253-56.

Ramirez JL, Galetti Jr. PM. DNA barcode and evolutionary relationship within Laemolyta Cope 1872 (Characiformes: Anostomidae) through molecular analyses. Mol Phyl Evol. 2015; 93:77-82.

Ratnasingham S, Hebert PDN. BOLD: the Barcode of Life Data System (www.barcodinglife.org). Mol Ecol Notes. 2007; 7:355-64. 
Rosso JJ, Mabragaña E, González Castro M, Díaz de Astarloa JM. DNA barcoding Neotropical fishes: recent advances from the Pampa Plain, Argentina. Mol Ecol Res. 2012; 12(6):999-1011.

Shibatta AO, Garavello JC. Uma nova espécie de Rhamdia Bleeker, 1858 (Siluriformes, Pimelodidae) do rio Iguaçu. P. B4. In: Encontro Brasileiro de Ictiologia, 11, 1995, Campinas, SP, Resumos... Campinas, SP, PUC, SBI.; 1995.

Shimabukuro-Dias CK, Costa Silva GJD, Ashikaga FY, Foresti F, Oliveira C. Molecular identification of the fish fauna from the pantanal flood plain area in Brazil. Mitochondr DNA A. 2016; 1-5.

Silfvergrip AMC. A systematic revision of the Neotropical catfish genus Rhamdia (Teleostei, Pimelodidae). [PhD Thesis]. Stockholm, Stockholm University; 1996.
Steinke D, Hanner R. The FISH-BOL collaborators protocol. Mitochondr DNA. 2011; 22(sup1):10-14.

Tamura K, Stecher G, Peterson D, Filipski A, Kumar S. MEGA6: molecular evolutionary genetics analysis version 6.0. Mol Biol Evol. 2013; 30(12):2725-29.

Ward RD, Hanner R, Hebert PDN. The campaign to DNA barcode all fishes, FISH-BOL. J Fish Biol. 2009; 74(2):329-56.

Ward RD, Zemlak TS, Innes BH, Last PR, Hebert PDN. DNA barcoding Australia's fish species. Phil Trans R Soc B. 2005; 360(1462):1847-57.

Submitted October 17, 2016

Accepted December 24, 2016 by Guillermo Ortí 